\title{
Investigating prevalence of pathogenic genes (ETA and TSST-1) in Staphylococcus aureus isolated from different wards of the hospitals by PCR method
}

\author{
Rashid Ramazanzadeh ${ }^{1}$, Hadi Mohammadi Talvar ${ }^{2}$,Mahdi Mirzaii ${ }^{3}$,Seyed Sajjad Hasheminasab ${ }^{4}$, Hanar Narenji ${ }^{5}$ \\ ${ }^{1}$ Cellular \& Molecular Research Center and Microbiology Department, Faculty of Medicine, \\ Kurdistan University of Medical Sciences, Sanandaj- Iran \\ ${ }^{2}$ Islamic Azad University, Science and Research Campus, Kurdistan branch, Sanandaj, Iran \\ ${ }^{3}$ Faculty of Medicine, Shahroud University of Medical Sciences, Shahroud, Iran \\ ${ }^{4}$ Faculty of Veterinary Medicine, Department of Parasitology, University of Tehran, Tehran-Iran \\ ${ }^{5}$ Department of Microbiology, School of Medicine Science, Sanandaj, Iran \\ *Corresponding author E-mail: Hadimohammadi202@gmail.com
}

Copyright () 2015 Rashid Ramazanzadeh et al This is an open access article distributed under the Creative Commons Attribution License, which permits unrestricted use, distribution, and reproduction in any medium, provided the original work is properly cited.

\begin{abstract}
Staphylococcus aureus is the most common pathogenic organisms in the hospitals and communities' infections. It is responsible for more than 80 percent of infectious diseases. The purpose of the present paper is to determine the incidence of Staphylococcus pathogenic genes isolated from different wards of hospitals by PCR method. This study included 61 Staphylococcus aureusisolates collected from different wards hospital, between 2011 and 2012 in University of Kurdistan (Toohhid and Besat hospitals). All isolates were previously identified as Staphylococcus aureusby a standard microbiological procedure. It isolates were incubated at $37 \dot{\mathrm{C}}$ for $24 \mathrm{~h}$ on blood agar; single colonies were tested with tube and slide coagulase, catalase tests and growth on Manito salt agar. Following genomic DNA extraction, the presence of ETA, TSST-1 genes was analyzed by PCR.61 strains of Staphylococcus aureushave been isolated from different wards of the hospital. Frequency of tst gene was $81 \%$ and eta gene was $47 \%$. Moreover, frequency of strains with both eta and tst genes was $40 \%$. Results of the present paper indicate that the prevalence of Staphylococcusaureus results on prevalence of eta and tst genes, and this is a matter of concern.
\end{abstract}

Keywords: TSST-1; ETA; Staphylococcus aureus; PCR Method; Penicillin.

\section{Introduction}

In 1950, the emergence of antibiotic-resistant strains provided a better understanding of epidemiology of Staphylococcus aureus disease. At first, emergence of penicillin was very helpful for treating Staphylococcus aureus infections. However, a considerable number of penicillin-resistant strains were obtained from Staphylococcus aureus infections in 1946[1]. Pathogenesis of Staphylococcus aureus could be because of its producing pyrogenic toxins. In fact, secretion of this toxin significantly stimulates T-lymphocytes, which are called superantigens (SAgs) [2], [3].So So far, far, 15 types of super antigens in Staphylococcus aureus have been recognized and Staphylococcal enterotoxin AM, exfoliative toxin A, B, and toxic shock syndrome toxin (TSST-1) are some samples of it. TSST-1 is a protein with molecule weight approximately equal to $24 \mathrm{kDa}$ and isoelectric point $6.8-7.2$, which are coded by tst gene of Staphylococcus aureus. Release of TSST-1 in blood flow results in acute clinical conditions such as toxic shock syndrome (TSS), syndrome of sudden death of infants, and Kawasaki syndrome's gene is presented in more than 70 percent of Staphylococcus aureus strains isolated from patients with TSS. TSS is characterized by skin rashes, high fever, severe fall in blood pressure, and muscle pains. If TSS is not treated up to one hour after the emergence of symptoms, it could result in a fatal shock. Two third of TSS is related to using tampons; however, some cases are related to localizing infections, surgery wounds and insects bites [4-6]. TSST-1 is one of the important factors related to 
the virulence of this bacterium; it is one of the pyrogenic toxins superantigens that has important effects on its host [7]. Exfoliative toxin is an extra cellular protein that causes staphylococcal scalded skin syndrome (SSSS) in children and teenagers. Three isoforms of exfoliative toxin have been isolated from human; the maximum frequency belongs to ETA and ETB, and the minimum frequency belongs to ETD. However, ETC has been isolated from animal infections and is not pathogenic to humans [8]. In this study, we are investigating prevalence of pathogenic genes tst and eta isolated from different wards of the hospital by PCR method.

\section{Methodology}

\subsection{Sample collecting}

This study included 61 Staphylococcus aureus isolates collected from different hospital wards, between 2011 and 2012 in Kurdistan University of medical sciences (Toohhid and Besat hospitals). All isolates were previously identified as Staphylococcus aureus by a standard microbiological procedure [9]. It isolates were incubated at $37 \dot{\mathrm{C}}$ for $24 \mathrm{~h}$ on blood agar and single colonies were tested with tube and slide coagulase, catalase, DNase tests, and growth on Mannitol salt agar. For confirmation of isolates as Staphylococcus aureus we used nuc gene codifies the nuclease-resistant to heat as a marker [10] After extracting DNA, five micro liters of each specimen with two micro liters diluted loading to dye was run over $1 \%$ agarose gel, and electrophoresis was done to ensure the presence of DNA.

\subsection{Staphylococcus aureus DNA extraction}

DNA Cinna Pure kit manufactured by Sina Gene was used to extract genomic DNA of the isolations of Staphylococcus aureus, After extracting DNA, $5 \mathrm{ml}$ of each specimen with $2 \mu \mathrm{l}$ diluted loading dye was run over $1 \%$ agarose gel and electrophoresis was done to ensure the presence of DNA. The extracted DNA should be kept in the refrigerator temperature of $4 \dot{\mathrm{C}}$. Some bacteria`s DNA can be kept in the refrigerator temperature of $-20 \dot{\mathrm{C}}$ but freezing can cause DNA to break. The long term maintenance is possible under the absolute ethanol or isopropanol in the $-20 \dot{C}[11]$.

\subsection{PCR amplification of nuc gene}

DNA template was prepared, purified and stored until needed at $-20 \dot{C}[12] P C R$ amplification of the nuc gene was performed to confirm Staphylococcus aureus. PCR was performed with $2 \mu l$ extracted template DNA, $2 \mu 1$ nuc primers

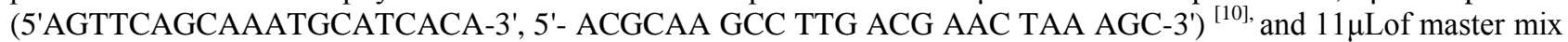
(polymerase Taq enzyme, $\mathrm{Mgcl}_{2}, \mathrm{dNTP}, \mathrm{SO}_{4}\left(\mathrm{NH}_{4}\right)_{2}$, TrisHCI, Tween - 20) and10 $\mu$ l deionized water a final volume of $25 \mu \mathrm{L}$. The thermal cycling program was as follows: initial denaturation $\left(5 \mathrm{~min}\right.$ at $\left.94^{\circ} \mathrm{C}\right)$; followed by 30 cycles of denaturation $\left(60 \mathrm{Sec}\right.$ at $\left.94^{\circ} \mathrm{C}\right)$, annealing $\left(60 \mathrm{Sec}\right.$ at $\left.55^{\circ} \mathrm{C}\right)$, and extension $\left(60 \mathrm{Sec}\right.$ at $\left.72^{\circ} \mathrm{C}\right)$; and a single extension $(7 \mathrm{~min}$ at $\left.72^{\circ} \mathrm{C}\right)$.

\subsection{PCR amplification of tst gene}

Detection of tst gene in S.aureus strains was carried out using PCR as described previously (Johnson \& Tyler, 1993). PCR was performed with $2 \mu \mathrm{L}$ extracted template DNA, $2 \mu \mathrm{L}$ tst primers (5'- ACCCCTGTTCCCTTATCATC-3', 5'TTTTCAGTATTTGTAACGCC-3' [13], and 12.5 $\mu$ l master mix (polymerase Taq enzyme, Mgcl $_{2}$, dNTP, $\mathrm{SO}_{4}\left(\mathrm{NH}_{4}\right)_{2}$, TrisHCI, Tween - 20) and $8.5 \mu 1$ deionized water in a final volume of $25 \mu$. The thermal cycling program was as follows: initial denaturation $\left(5 \mathrm{~min}\right.$ at $\left.94^{\circ} \mathrm{C}\right)$; followed by 30 cycles of denaturation $\left(60 \mathrm{sec}\right.$ at $\left.94^{\circ} \mathrm{C}\right)$, annealing $\left(60 \mathrm{sec}\right.$ at $\left.55^{\circ} \mathrm{C}\right)$, and extension $\left(60 \mathrm{sec}\right.$ at $\left.72^{\circ} \mathrm{C}\right)$; and a single extension $\left(10 \mathrm{~min}\right.$ at $\left.72^{\circ} \mathrm{C}\right)$.

\subsection{PCR amplification of eta gene}

Detection of tst in S.aureus strains was carried out using PCR as described previously [14] PCR was performed with 2 $\mu \mathrm{l}$ extracted template DNA, $2 \mu \mathrm{L}$ eta primers (5'- ATGGCAGCATCAGCTTGATA-3', 5'TTTCCAATAACCACCCGTTT-3'[13] and 12.5 $\mu$ l master mix (polymerase Taq enzyme, $\operatorname{Mgcl}_{2}, \mathrm{dNTP}, \mathrm{SO}_{4}\left(\mathrm{NH}_{4}\right)_{2}$, TrisHCI, Tween - 20) and $8.5 \mu$ l deionized water in a final volume of $25 \mu$. The thermal cycling program was as follows: initial denaturation $\left(5 \mathrm{~min}\right.$ at $\left.94^{\circ} \mathrm{C}\right)$; followed by 30 cycles of denaturation $\left(60 \mathrm{Sec}\right.$ at $\left.94^{\circ} \mathrm{C}\right)$, annealing $(60 \mathrm{Sec}$ at $\left.55^{\circ} \mathrm{C}\right)$, and extension $\left(60 \mathrm{Sec}\right.$ at $\left.72^{\circ} \mathrm{C}\right)$; and a single extension $\left(10 \mathrm{~min}\right.$ at $\left.72^{\circ} \mathrm{C}\right)$. 


\section{Results and Discussion}

As shown in Table 1 the frequency of pathogenic genes that encode eta, tst were high in isolate from pediatrics in compare with other wards. There were 61 strains isolated that include 35 clinical strains, 6 strains personnel colonized, and 20 strains hospital environment colonized strains as shown in Table 2.

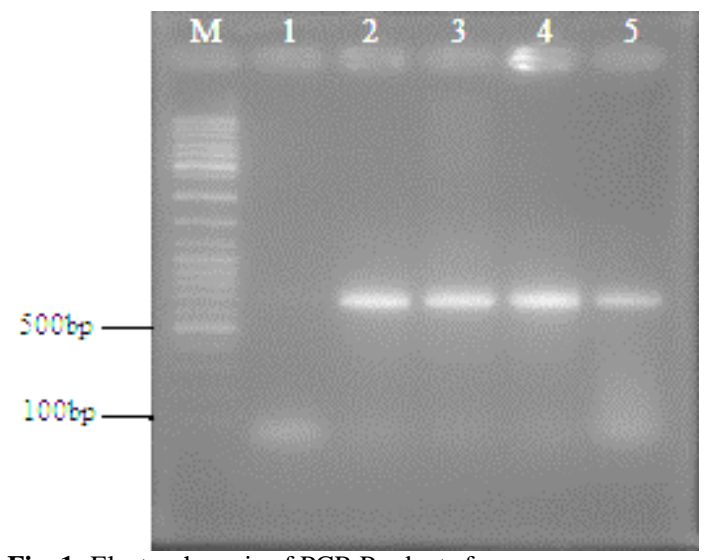

Fig. 1: Electrophoresis of PCR Products for nuc gene.

Line M: marker, molecular weight (100-1000 bp) Line 1: strain of negative control, without nuc gene 2, 3, 4: positive samples with nuc gene (680 bp), Line 5: strain of positive gene (ATCC 33591, S. aureus), with nuc gene Lines

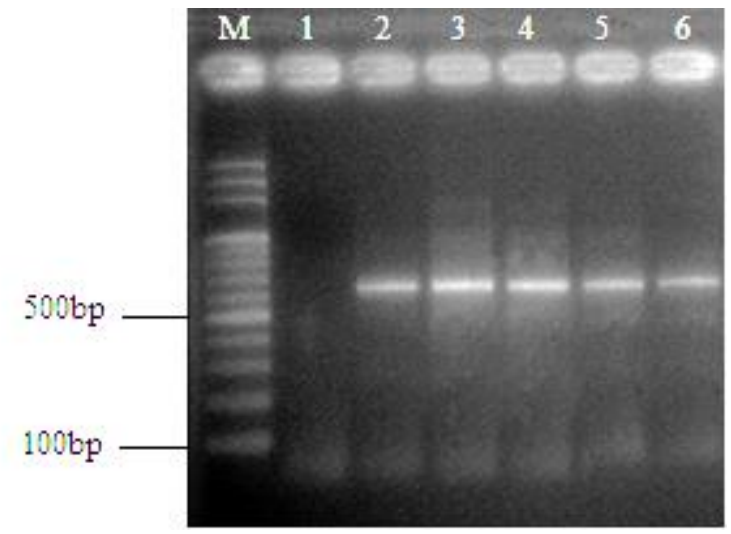

Fig. 2: Electrophoresis of PCR Products for eta gene.

Line M: marker, molecular weight (100-1000 bp) Line 1: strain of negative control, without eta gene Lines 2, 3, 4, 5: positive samples with eta gene $(650 \mathrm{bp})$, Line 6: strain of positive gene (ATCC 33591, S. aureus), with eta gene

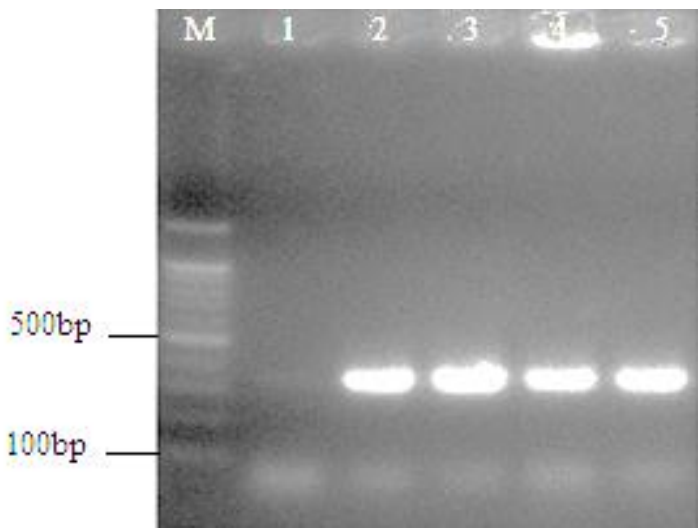

Fig. 3: Electrophoresis of PCR Products for tst gene.

Line M: marker, molecular weight (100-1000 bp) Line 1: strain of negative control, without tst gene 2, 3, 4: positive samples with tst gene (314 bp), Line 5: strain of positive gene (ATCC 33591, S. aureus), with tst gene Lines 
Table 1: Prevalence of eta and tst Genes among Different Wards of the Hospital

\begin{tabular}{lllll}
\multicolumn{5}{c}{ Table 1: Prevalence of eta and tst Genes among Different Wards of the Hospital } \\
\hline Wards & Sample & Isolates( number of strains) & tst (positive strains) & eta (positive strains) \\
\hline ICU & Urine,Trachea, Blood & 13 & $8(61 \%)$ & $3(23 \%)$ \\
Pediatric & Blood, Nasal swab. & 8 & $8(100 \%)$ & $5(62.5 \%)$ \\
Surgery & CSF, laryngoscope & 6 & $4(66 \%)$ & $3(50 \%)$ \\
Emergency & Patient bed & 5 & $3(60 \%)$ & $1(40 \%)$ \\
Operation & Nasal swab & 4 & $4(100 \%)$ & $2(50 \%)$ \\
Infant & Blood & 4 & $3(75 \%)$ & $1(25 \%)$ \\
Internal & Blood & 4 & $4(100 \%)$ & $2(50 \%)$ \\
Infection & Nasopharynx swab & 3 & $3(100 \%)$ & $3(100 \%)$ \\
Neurology & Urine & 2 & $1(50 \%)$ & $2(100 \%)$ \\
PICU & Secretion & 2 & $1(50 \%)$ & $1(50 \%)$ \\
Orthopedic & Patient bed & 2 & $2(100 \%)$ & $1(50 \%)$ \\
NICU & Blood & 1 & $1(100 \%)$ & Without gene \\
Cardiac & Urine & 1 & Without gene & Without gene \\
Burning & Biopsy & 1 & Without gene & $1(100 \%)$ \\
Oncology & Blood & 1 & $1(100 \%)$ & Without gene \\
CCU & Hand & 1 & $1(100 \%)$ & Without gene \\
Laboratory & Hand & 1 & $1(100 \%)$ & $1(100 \%)$ \\
Infection & Anesthesia machine & 1 & $1(100 \%)$ & Without gene \\
Neurology & Trolley & 1 & $1(100 \%)$ & $1(100 \%)$ \\
\hline
\end{tabular}

Table 2: Prevalence of eta and tst genes among Clinical Sample, Hospital Environment and Personnel in Hospitals (Positive Strains)

\begin{tabular}{|c|c|c|c|c|}
\hline \multirow{2}{*}{ Groups Number of strains } & Hospitals & \multirow{2}{*}{ tst gene $(\%)$} & \multirow{2}{*}{ eta gene $(\%)$} & \multirow{2}{*}{ tst and eta $(\%)$} \\
\hline & $\mathrm{T} \quad \mathrm{B}$ & & & \\
\hline clinical sample 35 & $15 \quad 20$ & $29(82)$ & $16(45)$ & $14(40)$ \\
\hline hospital environment 20 & $\begin{array}{ll}5 & 15 \\
\end{array}$ & $15(75)$ & $8(40)$ & $8(40)$ \\
\hline Personnel 6 & 4 & $5(83.3)$ & $2(33.33)$ & $3(50)$ \\
\hline \multicolumn{5}{|c|}{ Number of strains $=61$} \\
\hline
\end{tabular}

$\mathrm{T}=$ Toohhid hospital $\mathrm{B}=$ Besat hospital

Staphylococcus aureus is one of the most important human pathogens that has been a causative factor of acquired infections in community and hospital levels during the last decades [3], [14]. As major virulence factors in Staphylococcus aureus, TSST-1and ETA are pyrogenic toxins that have been implicated in host colonization, invasion of damaged skin and mucus and evasion of host defense mechanisms. [15], [16] The coordinated expression of S. aureus secreted and cell wall-associated virulence factor is regulated by a complex network, including the quorumsensing (QS) system agr and the well characterized virulence gene regulators [17]. In comparison with other methods, PCR is a proper, sensitive and cheap method for recognizing toxigenic genes [14]. Therefore, PCR method has been used in this study to recognize the rate of eta and tst genes. In overall, 61 strains of Staphylococcus aureus have been isolated from different wards of the hospital such as Pediatric 'Surgery remergency 'Operation 'Infant ، internal ، Infection ، Neurology ، PICU، orthopedic، NICU, Cardiac, Buring, Oncology ، CCU 'laboratory, anesthesia machine, ICU and trolley. 35 strains are isolated from patients, 6 strains from personnel and 20 strains from the hospital environment. In this study, frequency of tst gene was $81 \%$ and eta gene was $47 \%$. Moreover, frequency of strains with both eta and tst genes was $40 \%$. In this study, the most samples were collected from ICU, Pediatric wards. Results indicate more prevalence of tst and eta genes in these wards, so this issue would endanger of public health and Hygiene. Our results was in agreement with Shi studied that has done in children with impetigo, prevalence of eta gene in strains methicillin-resistant staphylococcus aureus (MRSA) and strains of methicillin sensitive (MSSA) were investigated. According to the results of this study, $61.5 \%$ of MRSA and 90.6\% of MSSA strains were carriers of eta gene[18]In the other hand, some other reports was lower frequency of tst gene was 48\%[19]The discrepancy in frequency in different geographical indicate dissemination of pathogenic organisms and it seems that we are exposure with high pathogenic organisms. This information in critical for nosocomial prevention committee. In fact, another research was done in Czech and showed that 48 strains out of 59 isolated strains were carriers of eta gene. In this research, 40 strains were isolated from sick children, 10 strains from nurses' hands and 5 strains from the equipment [20] Another research was done in 2005; in this research 103 strains of Staphylococcus aureus were isolated from community, hospital and patients with granulomatous. 12 strains out of 51 strains isolated from community, 5 strains out of 34 strains isolated from hospital and 4 strains out of 16 strains isolated from patients with granulomatous reported presence of tst gene[21]In the present research, 29 strains out of 35 strains isolated from the patients, 5 strains out of 6strains isolated from the personnel and 15 strains out of 20 strains isolated from the equipment included tst gene. Moreover, 16 strains out of 35 strains isolated from the patients, 4 strains out of 6 strains isolated from the personnel and 8 strains out of 20 strains isolated from the equipment included eta gene. 


\section{Conclusion}

The results showed that prevalence of Staphylococcus aureus that was carriers of eta and tst genes was a concerning issue. Report of this isolation in community, especially for children, old people and other cases with less immunity was hazardous. By considering a high value of colonization of this bacterium among healthy people that could arrive at 5060 percent in nasopharynx area and 5-30 percent in skin and hair, this issue would be considered as a significantly important issue.

\section{Acknowledgment}

We wish to thank laboratory staff at Faculty of medical science of Sanandaj.

\section{References}

[1] Casey, A., Lambert, PA, Elliott, T. Staphylococci. (2007). Int J Antimicrob Agents; 29:S23-S32. http://dx.doi.org/10.1016/S0924$\underline{8579(07) 72175-1}$.

[2] Fueyo, J., Mendoza, MC, Rodicio, MR., Muniz, J., Alvarez, M, Martín, MC. Cytotoxin and pyrogenic toxin superantigen gene profiles of Staphylococcus aureus associated with subclinical mastitis in dairy cows and relationships with macrorestriction genomic profiles. (2005). J Clin Microbiol; 43:1278-1284. http://dx.doi.org/10.1128/JCM.43.3.1278-1284.2005.

[3] Omoe, K., Hu, DL. Takahashi-Omoe, H., Nakane, A, Shinagawa, K. Comprehensive analysis of classicaland newly described staphylococcal superantigenic toxin genes in Staphylococcus aureus isolates. (2005). FEMS Microbiol Lett; 246:191-198. http://dx.doi.org/10.1016/j.femsle.2005.04.007.

[4] Sindhu, N., Sharma, A, Jain, V. Coagulase gene based molecular detection of Staphylococcus aureus directly frommastitic milk samples of Murrah buffalo. (2010). Buffalo Bull; 29:52-59.

[5] Chapaval, L., Moon, D., Gomes, J., Duarte, F, Tsai, S. An alternative method for Staphylococcus aureus DNA isolation. (2008). Arq Bras Med Vet Zootec; 60:299-306. http://dx.doi.org/10.1590/S0102-09352008000200004.

[6] Deurenberg, R., Vink, C., Kalenic, S., Friedrich, A., Bruggeman, C, Stobberingh, E. The molecular evolution of methicillin-resistant Staphylococcus aureus. (2007). Clin Microbiol Infect; 13:222-235. http://dx.doi.org/10.1111/j.1469-0691.2006.01573.x.

[7] El-Ghodban, A., Ghenghesh, KS., Márialigeti, K., Esahli, H, Tawil, A. PCR detection of toxic shock syndrome toxin of Staphylococcus aureus from Tripoli, Libya. (2006). J Med Microbiol; 55:179-182. http://dx.doi.org/10.1099/jmm.0.46162-0.

[8] Abimanyu, N., Murugesan, S, Krishnan, P. High Prevalence of Exfoliative Toxins Among Carrier Isolates of Staphylococcus aureus from Healthy Individuals from Various Communities in Chennai, South India. (2013). Indian J Microbiol; 53:288-290. http://dx.doi.org/10.1007/s12088-013-0360-9.

[9] Mahon, C., Manuselis, G, Lehman, D. Textbook of Diagnostic Microbiology, Saunders. ISBN 0-7216-7917-X; 2000.

[10] Wang, S-C., Wu, C-M., Xia, S-C., Qi, Y-H., Xia, L-N, Shen, J-Z. Distribution of superantigenic toxin genes in $<$ i $>$ Staphylococcus aureus $</ i>$ isolates from milk samples of bovine subclinical mastitis cases in two major diary production regions of China. (2009). Veterinary microbiology; 137:276-281. http://dx.doi.org/10.1016/j.vetmic.2009.01.007.

[11] Drews, TD, Temte, JL, Fox, BC. Community-associated methicillin-resistant Staphylococcus aureus: review of an emerging public health concern. (2006). WMJ-MADISON-; 105:52.

[12] Maniatis, T., Fritsch, EF, Sambrook, J. Molecular cloning: a laboratory manual: Cold Spring Harbor Laboratory Cold Spring Harbor, NY; 1982.

[13] Mehrotra, M., Wang, G, Johnson, WM. Multiplex PCR for Detection of Genes forStaphylococcus aureus Enterotoxins, Exfoliative Toxins, Toxic Shock Syndrome Toxin 1, and Methicillin Resistance. (2000). J Clin Microbiol; 38:1032-1035.

[14] Johnson, W., Tyler, S., Ewan, E., Ashton, F., Pollard, D, Rozee, K. Detection of genes for enterotoxins, exfoliative toxins, and toxic shock syndrome toxin 1 in Staphylococcus aureus by the polymerase chain reaction. (1991). J Clin Microbiol; 29:426-430.

[15] Adwan, GM., Abu-Shanab, B., Adwan, K, Jarrar, N. Toxigenicity of Staphylococcus aureus isolates from Northern Palestine. (2006). Emirates Medical Journal; 24:127.

[16] Udo, EE, Al-Mufti, S, Albert, MJ. The prevalence of antimicrobial resistance and carriage of virulence genes in Staphylococcus aureus isolated from food handlers in Kuwait City restaurants. (2009). BMC Res Notes; 2:108. http://dx.doi.org/10.1186/1756-0500-2-108.

[17] Cotar, A-I., Chifiriuc, M-C., Dinu, S., Bucur, M., Iordache, C., Banu, O., Dracea, O., Larion, C, Lazar, V. Screening of molecular virulence markers in Staphylococcus aureus and Pseudomonas aeruginosa strains isolated from clinical infections. (2010). International journal of molecular sciences; 11:5273-5291.

[18] Shi, D., Higuchi, W., Takano, T., Saito, K., Ozaki, K., Takano, M., Nitahara, Y, Yamamoto, T. Bullous Impetigo in Children with MethicillinResistant Staphylococcus aureus Alone or in Combination with Methicillin-Susceptible S. aureus-Genetic Characteristics, Including Assessment of Exfoliative Toxin Gene Carriage. (2011). J Clin Microbiol.

[19] Xie, Y., He, Y., Gehring, A., Hu, Y., Li, Q., Tu, S-I, Shi, X. Genotypes and toxin gene profiles of Staphylococcus aureus clinical isolatesfrom China. (2011). PLoS One; 6:e28276. http://dx.doi.org/10.1371/journal.pone.0028276.

[20] Rǔžičková, V., Voller, J., Pantǔček, R., Petráš, P, Doškař, J. Multiplex PCR for detection of three exfoliative toxin serotype genes inStaphylococcus aureus. (2005). Folia Microbiol (Praha); 50:499-502. http://dx.doi.org/10.1007/BF02931437.

[21] Deurenberg, RH, Nieuwenhuis, RF., Driessen, C., London, N., Stassen, FR., Tiel, FH, Stobberingh, EE, Vink, C. The prevalence of the Staphylococcus aureus tst gene among community-and hospital-acquired strains and isolates from Wegener's Granulomatosis patients. (2005). FEMS Microbiol Lett; 245:185-189. http://dx.doi.org/10.1016/j.femsle.2005.03.002. 